\title{
Climatic FACTORS, REPRODUCTIVE SUCCESS AND POPUlaTION DYNAMICS IN THE MONTANE Vole, MICROTUS MONTANUS
}

\section{AELITA J. PINTER $\uparrow$ DEPARTMENT OF BIOLOGICAL SCIENCES UNIVERSITY OF NEW ORLEANS $\uparrow$ LA}

\section{$\uparrow$ OBJECTIVES}

Multiannual fluctuations in population density ("cycles") of small rodents have been known since antiquity (Elton 1942). Numerous hypotheses have been proposed to explain this phenomenon (for reviews see Finerty 1980, Taitt and Krebs 1985). However, none of these hypotheses, alone or in combination, has been able to explain the causality of cycles, although recently removal of parasites was shown to prevent population cycles in the red grouse, Lagopus lagopus scoticus (Hudson et al. 1998).

The objectives of this long-term study are to determine whether environmental variables, possibly acting through reproductive responses, contribute to the multiannual fluctuations of the montane vole, Microtus montanus.

\section{METHODS}

Microtus montanus were live trapped at two times of the year: the se cond half of May (spring study period) and mid-July to midAugust (summer study period). Animals were killed with an overdose of Metofane as soon as possible after capture. Animals were aged using weight, total length and pelage characteristics. The digestive tract and the liver were examined for the presence of parasites. Reproductive organs, the spleen and the adrenal glands were collected from all animals and preserved in
Lillie's buffered neutral formalin for further histological study. Flat skins were prepared from all animals.

Population density was estimated on the basis of the trapping success in a permanent grid (established in 1970). The grid consists of 121 stations placed in a square, $5 \mathrm{~m}$ apart, 11 stations $(50 \mathrm{~m})$ on a side. Each station is marked with a stake. Trapping in this grid was performed only during the summer study period. One unbaited Sherman livetrap was set at each station. Additional trapping was carried out in nearby meadows to obtain additional females for litter size determination. In these areas, traps were not set in a regular pattern; rather, they were placed only in locations showing recent vole activity (cuttings, droppings).

During the spring study period trapping was carried out in a number of sites, all well removed from the permanent grid. The objective of trapping during the spring study period was to determine (on the basis of embryo size) the onset of reproduction on a population-wide basis. The reason for not trapping the grid during the spring study period was to leave the site as undisturbed as possible since the grid is the major source of information on population density. In order to ascertain the effects of habitat/density on population dynamics of $M$. montanus in Grand Teton National Park, populations of these rodents were monitored in both, optimal and marginal habitats. 


\section{RESULTS AND DISCUSSION}

In 2000 spring was unusually early, in complete contrast to the unusually late spring in 1999. Consequently, it was not surprising that all females were pregnant with their second litter. It was also not surprising that litter sizes were unusually large since the second litter in Microtus montanus is significantly larger than the first (Negus and Pinter 1965). It was expected that the early onset of breeding would enable the voles to produce an additional litter in the 2000 breeding season. An early production of the first litter would have significant repercussions on population dynamics of $M$. montanus in 2000. The first litter would have significant repercussions on population dynamics of $M$. montanus in 2000. The first litter always reproduces in the year of its birth. An early production of the first litter also means an early addition of breeders (as opposed to merely individuals - Pinter 1986, 1988). The early onset of reproduction would be particularly important in 2000 because a fairly small population had overwintered (as indicated not only by a paucity of sign-runways, cuttings - but also by low trap success). All of these indices of population density were lower in 2000 than in 1999.

During the summer study period it became clear that even the early onset of reproduction had been unable to compensate for the small overwintering population that constituted the initial breeding stock for 2000 . By the end of the summer study period the population density of Microtus. Montanus in 2000 declined below the levels seen in 1999.

In 1998 population cycles at one of the study sites had become desynchronized from all the other populations being monitored. This asynchrony persisted in 1999 and continued into 2000. Whereas all the synchronous populations declined in density in 2000 , the asynchronous population nearly quadrupled over the 1999 levels. As in 1999, the rise in the population density of $M$. montanus correlated with a complete exclusion of Microtus pennsylavnicus from this site. This phenomenon has been observed repeatedly throughout this long-term study.

Cuterebrid parasitism of $M$. montanus (Pinter et al. 1997) reappeared in the summer of 2000, albeit at extremely low levels.
Nevertheless, this is noteworthy since such parasitism was not observed in the two preceding seasons.

\section{CONCLUSIONS}

The early onset of reproduction in Microtus montanus in 2000 failed to compensate for the small overwintering numbers of spring breeders as populations of Microtus montanus declined at all but one study site. This exceptional site, showing a quadrupling of its population density above the 1999 levels is of particular interest. Such dramatic divergence of population dynamics in one valuable precisely because it is an exception: it may provide clues to an as yet undetected or unappreciated factor that helps drive population dynamics in these rodents.

\section{ACKNOWLEDGEMENTS}

I gratefully acknowledge the availability of the facilities at the University of WyomingNational Park Service Research Center and the enthusiastic support of the Research Center staff without which it would have been impossible to accomplish this work. I am particularly grateful to the Steering Committee of the UW-NPS Research Center and to the National Park Service for their cognizance of the fact that the understanding of microtine cycles can be gained only from long-term studies.

\section{LITERATURE CITED}

Elton, C.S. 1942. Voles, mice and lemmings. Clarendon Press, Oxford. 496 pp.

Finerty, J.P. 1980. The Population Ecology of Cycles in Small Mammals. Mathematic Theory and Biological Fact. Yale Univ. Press, New Haven. 234 pp.

Hudson, P.J., A.P. Dobson and D. Newborn. 1998. Prevention of population cycles by parasite removal. Science, 282: 22562258. 
Negus, N.C., P.J. Berger, and A.J. Pinter. 1992. Phenotypic plasticity of the montane vole (Microtus montanus) in unpredictable environments. Can. J. Zool. 70:2121-2124.

Negus, N.C. and A.J. Pinter. 1965. Litter sizes of Microtus montanus in the laboratory. J. Mammal. 46: 434-437.

Pinter, A.J. 1986. Population dynamics and litter size of the montane vole, Microtus montanus. Can J. Zool. 64:1487-1490.
Pinter, A.J. 1988. Multiannual fluctuations in precipitation and population dynamics of the montane vole, Microtus montanus. Can. J. Zool. 66:2128-2132.

Taitt, M.J. and C.J. Krebs. 1985. Population dynamics and cycles In: Biology of New World Microtus. R.H. Tamarin, ed. Spec. Publ. Amr. Soc. Mannual. 8:567-620. 